\title{
EFFICIENCY OF ISLAMIC INSURANCE IN INDONESIA
}

\author{
Rachma Indrarini \\ Universitas Negeri Surabaya, Indonesia \\ e-mail: rachmaindrarini@unesa.ac.id \\ Clarashinta Canggih \\ Universitas Negeri Surabaya, Indonesia \\ e-mail: clarashintacanggih@unesa.ac.id
}

\begin{abstract}
:
This paper aims to measure Islamic Insurance Efficiency in Indonesia. This paper uses quantitative data analysis through Data Envelopment Analysis to assess efficiency. Input variables in this study are total assets, expenses and claims payments, while the output variables used are tabaru income and funds during 2012-2016. The objects of this paper arePT. AJS Amanahjiwa Giri Arta, PT AJS Al Amin and PT Asuransi Takaful Keluarga.The result shows thatin general, Islamic insurance in Indonesia is not yet efficient.
\end{abstract}

Keywords: eficiency, Islamic insurance, DEA

\section{Pendahuluan}

Lembaga Keuangan Syariah (LKS) di Indonesia mengalami perkembangan yang pesat baik dari segi jenis maupun jumlahnya. Dari tahun ke tahun terdapat variasi jenis lembaga keuangan syariah yang terbentuk misalnya perusahaan modal ventura, perusahaan pembiayaan infrastruktur syariah, perusahaan pembiayaan sekunder perumahan syariah dan lain sebagainya. Selain jenis lembaga keuangan syariah yang mengalami perkembangan tiap tahunnya, jumlah kantor layanan lembaga keuangan syariah juga mengalami penambahan tiap tahunnya. Salah satu diantaranya adalah kantor layanan bank syariah di Indonesia, yang perkembangannya dapat dilihat pada tabel 1 berikut

Tabel 1: Jumlah Kantor Layanan Bank syariah di Indonesia

\begin{tabular}{|l|c|c|c|c|c|c|}
\hline \multicolumn{1}{|c|}{ Indikator } & 2014 & $\mathbf{2 0 1 5}$ & $\mathbf{2 0 1 6}$ & $\mathbf{2 0 1 7}$ & $\mathbf{2 0 1 8}$ & $\begin{array}{c}\text { Feb } \\
\mathbf{2 0 1 9}\end{array}$ \\
\hline BankUmumSyariah & 2163 & 1990 & 1869 & 1825 & 1875 & 1886 \\
\hline UnitUsaha Syariah & 320 & 311 & 332 & 344 & 354 & 360 \\
\hline BankPembiayaan RakyatSyariah & 439 & 446 & 453 & 441 & 495 & 470 \\
\hline \multicolumn{1}{|c|}{ Jumlah Kantor } & 2922 & 2747 & 2654 & 2610 & 2724 & 2716 \\
\hline
\end{tabular}

Sumber : OJK, 2019a

Dari tabel 1 dapat dilihat bahwa perkembangan jumlah kantor layanan unit usaha syariah mengalami perkembangan dari tahun ke tahun. Hal ini 
menunjukkan bahwa lembaga keuangan syariah, khususnya bank syariah, terus mengembangkan dirinya mengikuti kebutuhan masyarakat. Selain bank syariah terdapat lembaga keuangan syariah lain yang lahir dan berkembang untuk memenuhi kebutuhan masyarakat terkait jasa layanan keuangan yang berbasis syariah. Salah satu diantaranya adalah asuransi syariah.

Asuransi syariah merupakan lembaga keuangan syariah yang menawarkan jasa perlindungan kepada masyarakat Indonesia. Asuransi syariah mencoba untuk mewadahi kebutuhan masyarakat terkait dengan perlindungan, seperti perlindungan kesehatan, perlindungan asset, pendidikan dan lain sebagainya.Konsep utama dari asuransi syariah adalah saling tolong menolong. Hubungan antar manusia diartikan sebagai hubungan keluarga yang hendaknya dapat saling tolong menolong atau saling menanggung. Orang yang dipandang mampu dapat menolong orang yang membutuhkan dan sebaliknya. Sebagaimana terdapat dalam firman Allah Q.S AlZukhruf:32

"...Kami telah meninggikan sebagian mereka atas sebagian yang lain beberapa derajat, agar sebagian mereka dapat mempergunakan sebagian yang lain. Dan rahmat Tuhanmu lebih baik dari apa yang mereka kumpulkan"

Kebutuhan masyarakat untuk meredam kekhawatiran terkait dengan biaya kesehatan, pendidikan dan aset merupakan upaya untuk meminimalisir resiko yang ada menciptakan pasar bagi industri asuransi syariah di Indonesia. PT. Takaful merupakan asuransi syariah pertama di Indoesia yang berdiri sejak tahun 1994. Kesuksesan PT. Takaful dalam melayani masyarakat Indonesia terkait dengan perlindungan, membawa perusahaan - perusahaan asuransi lainnya memiliki unit usaha syariah. Berdasarkan data OJK pada Februari 2019 terdapat 13 industri asuransi syariah dan 49 unit usaha asuransi syariah di Indonesia (OJK, 2019b). Jika dilihat dari perkembangan jumlah perusahaan asuransi syariah, sepanjang tahun 2016-2019 berdasarkan data OJK dapat dilihat pada Tabel 2 berikut:

Tabel 2. Daftar Perusahaan Asuransi Syariah

\begin{tabular}{|c|r|}
\hline Tahun & Total Aset \\
\hline 2015 & 26,519 \\
\hline 2016 & 27,079 \\
\hline 2017 & 33,484 \\
\hline 2018 & 41,959 \\
\hline Feb 2019 & 42,692 \\
\hline
\end{tabular}

Sumber: Statistik IKNB Syariah 20162019, data diolah

Hal ini membuktikan bahwa antusiasme masyarakat Indonesia terkait hadirnya asuransi syariah di Indonesia cukup baik. Jika dilihat dari besaran aset yang dimiliki oleh asuransi syariah, sepanjang tahun 2015 - Feb 2019 dapat dilihat pada Tabel 3. 
Tabel 3. Daftar Aset Perusahaan Asuransi Syariah

\begin{tabular}{|c|r|}
\hline Tahun & Total Aset \\
\hline 2015 & 26,519 \\
\hline 2016 & 27,079 \\
\hline 2017 & 33,484 \\
\hline 2018 & 41,959 \\
\hline Feb 2019 & 42,692 \\
\hline
\end{tabular}

Sumber: Statistik IKNB Syariah 20162019

Merujuk pada perkembangan total aset pada asuransi syariah di Indonesia belum dapat dikatakan menunjukkan kinerja yang baik. Kinerja merupakan suatu ukuran terpenting dalam perusahaan yang diperoleh dari hasil kegiatan operasional perusahaan. Salah satu ukuran kinerja perusahaan dapat dilihat dari laba yang dihasilkan. Dapat dikatakan bahwa jika laba perusahaan mengalami penurunan maka kinerja perusahaan juga menurun. Hal inilah yang dialami oleh perusahaan asuransi syariah di Indonesia saat ini.

Selain melihat pada besaran laba yang dihasilkan, kinerja sebuah perusahaan dapat dilihat juga dari nilai efisiensinya. Efisiensi berkaitan dengan pengelolaanhubungan input dan output yaitu bagaimanamengalokasikan faktorfaktor produksi yangtersedia secara optimal untuk dapat menghasilkanoutput yang maksimal. Sebuah perusahaan dikategorikan memiliki tingkat efisiensi yang tinggi apabila dapat menghasilkan kuantitas output lebih banyak dengan input tertentu atau menghasilkan kuantitas ouput tertentu dengan input lebih sedikit (Abidin dan Endri, 2010).
Pengukuran kinerja perusahaan dengan menggunakan efisiensi juga dapat melihat ukuran input yang digunakan dan output yang dihasilkan. Sehingga jika ditemukan input atau output yang menimbulkan ketidakefisienan dapat segera diambil tindakan perbaikan melalui pengurangan ataupun penambahan input atau output.

Pada lembaga keuangan syariah, hasil pengukuran efisiensi digunakan sebagai bahan evaluasi bagi manajemen lembaga keuangan syariah terkait dengan kinerja yang telah diraih oleh perusahaan. Perusahaan dapat meningkatkan ukuran perusahaan, kapitalisasi, profitabilitas, dan juga mengurangi biaya-biaya untuk mengoptimalkan efisiensi pada perusahaan tersebut (Fiafiah, dan Darwanto, 2019). Pengukuran efisiensi pada perusahaan asuransi syariah diperlukan untuk melakukan evaluasi atas kinerja asuransiasuransi syariah yang beroperasi. Evaluasi atas kinerja perusahaan asuransi syariah tersebut pada akhirnya dapat digunakan untuk menentukan daya saing dalam industri yang pada akhirnya akan meningkatkan kepercayaan publik (Antonio, Ali, dan Akbar, 2013; Tuffahati, Mardian, dan Suprapto, 2016; Sabiti, Effendi, dan Novianti, 2017).

Dalam mengukur efisiensi pada asuransi syariah ada beberapa jenis variabel input dan output yang digunakan dalam pengukuran. Variabel input yang digunakan untuk mengukur efisiensi asuransi syariah adalah aset, beban, 
pembayaran klaim, biaya komisi, biaya operasional, biaya manajemen, biaya umum dan administrasi, dan total ekuitas (Abduh, 2012; Bernada, Sumarwan, dan Hosen, 2016; Sabiti, Effendi, dan Novianti, 2017; Tufahati, Mardian, dan Suprapto, 2016; Ningsih, dan Suprayogi, 2017; Rusydiana, dan Nugroho, 2017; Sunarsih, Fitriyani, 2018). Sementara untuk variabel output yang digunakan adalah dana tabarru', premi, pendapatan usaha, kontribusi bruto, pendapatan investasi, komisi (Abduh, 2012; Bernada, Sumarwan, dan Hosen, 2016; Sabiti, Effendi, dan Novianti, 2017; Tufahati, Mardian, dan Suprapto, 2016; Ningsih, dan Suprayogi, 2017; Rusydiana, dan Nugroho, 2017, Sunarsih, Fitriyani, 2018).

Bernada, Sumarwan, dan Hosen (2016) mengidentifikasikan bahwa pada tahun 2011-2014, 14 perusahaan asuransi jiwa syariah di Indonesia belum efisien baik secara ekonomi, teknis, maupun skala. Tufahati (2016) menyatakan belum efisiennya asuransi syariah di Indonesia pada tahun 2012 - 2014. Menurut Sabiti, Effendi, Novianti (2017) dari 14 perusahaan asuransi syariah dan 12 perusahaan asuransi umum syariah pada tahun 20132015 belum ada perusahaan asuransi yang mencapai efisiensi. Lebih lanjut dikatakan bahwa dari 8 perusahaan asuransi jiwa syariah hanya $15 \%$ yang memiliki nilai efisiensi 100\% (Rusydiana, 2017).

Mayoritas penelitian terkait efisiensi asuransi syariah di Indonesia menunjukkan bahwa terjadi inefisiensi pada mayoritas perusahaan asuransi syariah di
Indonesia. Penelitian ini mencoba menggunakan variabel input dan variabel output yang berbeda dari penelitian sebelumnya dan menggunakan periode yang berbeda serta spesifik pada perusahaan asuransi jiwa syariah di Indonesia. Dalam penelitian ini variable input yang digunakan adalah total asset, pembayaran klaim dan beban. Sedangkan variable output dalam penelitian ini adalah pendapatan dan dana tabaru'. Diharapkan terdapat hasil nilai efisiensi sehingga terlihat kinerja asuransi jiwa syariah pada periode 2012-2016.

\section{Rumusan Masalah}

Berdasarkan permasalahan yang telah dijabarkan di atas, maka dapat disimpulkan rumusan masalah sebagai berikut: Bagaimanakah tingkat efisiensi asuransi jiwa syariah di Indonesia pada periode 2012-2016?

\section{Tinjauan Pustaka}

Asuransi Syariah

Kata asuransi berasal dari bahasa Inggrisyaitu insurance, sedangkan dalam bahasa Indonesia disebut dengan 'pertanggungan'. Dalam Undang-Undang No.2 Tahun 1992 disebutkan bahwa asuransi adalah sebuah perjanjian antara dua pihak atau lebih, dimana satu pihak mengikatkan diri pada pihak lain dengan menerima premi untuk memberi penggantian atas kerugian, kerusakan, atau kehilangan keuntungan yang diharapkan, yang mungkin akan diderita akibat peristiwa yang tidak pasti. Dalam 
asuransi mengandung empat unsur yakni 1) pihak tertanggung, 2) pihak penanggung, 3) peristiwa, dan 4) kepentingan (Amrin, 2006:7).

Berdasarkan Fatwa DSN MUI NO : 21/DSN-MUI/X/2001, asuransi syariah merupakan sebuah usahasaling melindungi dan tolongmenolong di antara sejumlah orang/pihak melalui investasi dalam bentuk aset dan /atau tabarru' yang memberikan pola pengembalian untuk menghadapi resiko tertentu melalui akad yang sesuai dengan syariah.

Salah satu tujuan dasar syariah (maqashid as shariah) adalah memelihara harta, keturunan, dan jiwa. Asuransi merupakan cara untuk meminimalisasi risiko yang dihadapi manusia dalam kehidupannya. Sehingga pada dasarnya asuransi syariah tidak bertentangan dengan syariah Islam. Asuransi syariah merupakan sebuah bentuk usaha pengamalan perintah Allah sebagaimana tertuang dalam Q.S An -Nisa ayat 9

"Dan hendaklah takut (kepada Allah) orang-orang yang sekiranya mereka meninggalkan keturunan yang lemah di belakang mereka yang mereka khawatir terhadap (kesejahteraannya)" (Q.S 4:9)

Konsep dasar asuransi syariah adalah prinsip tolong-menolong dalam mengantisipasi kemungkinan sebuah peristiwa terjadi. Hal ini sesuai dengan Q.S Al Maidah ayat 2

"Dan tolong-menolonglah kamu dalam (mengerjakan) kebajikan dan takwa, dan jangan tolong-menolong dalam berbuat dosa dan pelanggaran. Dan bertakwalah kamu kepada
Allah, sesungguhnya Allah amat berat siksa-Nya"(Q.S 5:2)

Dalam ayat tersebut terdapat perintah untuk saling tolong menolong pada hal-hal yang membawa kepada kebaikan dan ketakwaan.

Jenis usaha perasuransian di Indonesia dapat dibedakan berdasakan pada objek yang diasuransikan. Berdasarkan Undangundang No.40 tahun 2014 tentang perasuransian, disebutkan bahwa ada tiga jenis usaha asuransi syariah yakni asuransi umum syariah, asuransi jiwa syariah, dan reasuransi syariah. Sedangkan akad yang digunakan pada asuransi syariah adalah akad tijarah dan akad tabarru. Hal ini tercantum dalam fatwa DSN MUI NO : 21/DSNMUI/X/2001 yang menjelaskan bahwa akad tijarah adalah akad untuk tujuan komersial dan akad tabarru adalah akad untuk tolongmenolong.

Dalam konsep asuransi syariah, perusahaan asuransi hanya bertindak sebagai wakil dari pemilik dana untuk mengelola dana kontribusi peserta yang dibedakan menjadi dana tabarru' (untuk sistem yang tidak mengandung tabungan) dan dana tabarru' dan dana investasi (untuk sistem yang mengandung tabungan). Dimana dana tabarru' ini tidak berpindah kepemilikan dan digunakan untuk membantu peserta lain yang mengalami musibah (Muhammad, 2007:88).

Efisiensi

Dalam menjalankan kehidupan Islam mengajarkan agar 
umatnya selalu bersikap sederhana dan tidak berlebihan sebagaimana tercantum dalam Al Quran Surat AlIsro Ayat 26-29.

"Dan berikanlah kepada keluargakeluarga yang dekat akan haknya, kepada orang miskin dan orang yang dalam perjalanan dan janganlah kamu menghambur-hamburkan (hartamu) secara boros. Sesungguhnya pemborospemboros itu adalah Saudara-saudara syaitan dan syaitan itu adalah sangat ingkar kepada Tuhannya. Dan jika kamu berpaling dari mereka untuk memperoleh rahmat dari Tuhanmu yang kamu harapkan, Maka Katakanlah kepada mereka Ucapan yang pantas. Dan janganlah kamu jadikan tanganmu terbelenggu pada lehermu dan janganlah kamu terlalu mengulurkannya Karena itu kamu menjadi tercela dan menyesal."

Arti kata berlebihan dan tidak boros dapat diterapkan pada sebuah perusahaan, dimana dalam pengelolaan sebuah perusahaan managemen harus efisien. Efisiensi tidak terbatas pada masalah biaya namun efisiensi dapat berupa bagaimana suatu perusahaan berupaya mengolah sumber daya yang ada untuk menghasilkan hasil yang optimal.

Efisiensi terdiri dari efisiensi teknis (technical eficiency) yang merefleksikan kemampuan dari suatu perusahaan untuk memaksimalkan output dengan input tertentudan efisiensi alokatif (allocative efficiency) yang merefleksikan kemampuan dari suatu perusahaan yang memanfaatkan input secara optimal dengan tingkat harga yang telah ditetapkan. Kedua ukuran ini kemudian dikombinasikan menjadi efisiensi ekonomis (total) (Kusuma: 2008).Lebih lanjut efisiensi teknis dapat diukur dalam dua metode yakni pengukuran berorientasi input (Input-Oriented Measures) yang menunjukan sejumlah input dapat dikurangi secara proposional tanpa mengubah jumlah output yang dihasilkan dan pengukuran berorientasi output (Output-Oriented Measures) mengukur jika sejumlah output dapat ditingkatkan secara proposional tanpa mengubah jumlah input yang digunakan.

Pada perusahaan asuransi syariah, sebuah perusahaan dapat dikatakan efisien jika perusahaan dapat menyediakan dana tabarru', untuk membayar kewajiban klaim pada peserta, dan dapat meningkatkan pendapatan. Hal ini menunjukkan bahwa perusahaan asuransi syariah mampu mengelola kekayaan dan melakukan proses underwriting yang tepat sehingga pengelolaan pembayaran klaim dan beban perusahaan dapat dilaksanakan dengan baik. Pengelolaan dana yang baik akan terlihat dari jumlah saldo dana tabarru' dan pendapatan perusahaan ( Ningsih dan Suprayogi, 2017).

\section{Metode Penelitian}

Jenis pendekatan penelitian ini adalah penelitian kuantitatif deskriptif. Pada penelitian ini, akan mengukur nilai efisiensi dengan mengolah variabel input dan output. Pengolahan variable menggunakan DEA (Data Envelopment Analysis). DEA merupakansuatu pendekatan 
nonparametrik yang pada dasarnya merupakan pengembangan dari Linear Programming (LP). Data Envelopment Analysis berfungsi untuk menilai efisiensi dalam penggunaan sumber daya (input) untuk mencapai hasil (output) yang tujuannya untuk maksimalisasi efisiensi.

Variabel input yang digunakan dapalam penelitian ini adalah total asset, beban dan pembayaran klaim. Sedangkan variable output yang digunakan adalah pendapatan dan dana tabaru'. Sumber data yang digunakan adalah data sekunder yang diperoleh dari laporan keuangan perusahaan asuransi syariah yang dipublikasikan.

Obyek yang digunakan dalam penelitian ini adalah perusahaan Asuransi Syariah dengan kriteria sebagai berikut:

1. Perusahaan Asuransi Jiwa Syariah yang terdaftar dalam direktori Industri Keuangan Non-Bank Syariah (IKNB Syariah) OJK pada tahun 20122016 dan

2. Memiliki data keuangan yang dipublikasikan dan lengkap pada tahun2012-2016.

Berdasarkan kriteria yang disebutkan di atas maka diperoleh tiga perusahaan asuransi jiwa syariah yang digunakan sebagai obyek penelitian yakni PT. AJS Amanahjiwa Giri Arta, PT Asuransi Jiwa Syariah Al Amin dan PT Asuransi Takaful Keluarga.

Analisis efisiensi yang digunakan pada penelitian ini adalah efisiensi teknik. Efisiensi teknis digunakan untuk mengukur kemampuan dari sebuah perusahaan untuk mencapai tingkatan output yang maksimal dari komponen input yang digunakan. Efisiensi teknis murni untuk mengukur kemampuan perusahaan dalam menghindari pemborosan dengan memproduksi sebanyak mungkin output dengan menggunakan input yang sediki (Hassine \& Limani, 2014).

\section{Hasil Penelitian}

Hasil tabulasi data variabel input dan variabel output tahun 2012-2016 untuk masing-masing perusahaan asuransi jiwa syariah yang digunakan pada penelitian ini disajikan dalam tabel 4, tabel 5 dan tabel 6. Berikut data yang didapat dari hasil laporan keuangan tahun 2012-2016.

Tabel 4

Data Asuransi PT. Asuransi Jiwa Syariah Al Amin

\begin{tabular}{|c|c|c|c|c|c|c|}
\hline & & 2012 & 2013 & 2014 & 2015 & 2016 \\
\hline APUT & Iotal Aset & $80,685.95$ & 78.69 & 81.239 & $71.50 \mathrm{t}$ & 68.929 \\
\hline & Betan & $4,289.01$ & 14.056 & 17,573 & 18380 & 18.88 \\
\hline & Pentbayaran Klaim & . & 9.469 & 14,325 & 4.418 & 8.434 \\
\hline OUTPUT & Pendepatanan & 1.35 & 6.14 & 7903 & 1.41.2. & 6.999 \\
\hline & Dana Tabaru' & 1.27 & 862 & $27 \%$ & 2236 & 3.55 \\
\hline
\end{tabular}

Sumber : Hasil olah data

Berdasarkan tabel 4, terlihat bahawa asuransi syariah $\mathrm{Al}$ Amin pada tahun 2012 dan 2013 tidak memiliki pemasukan dana tabaru' dan tidak membayarkan dana klaim kepada pemegang asuransi. Berbeda dengan tahun 2014 dan 2016 pembayaran klaim lebih besar 
dibandingkan dengan dana tabaru' yang ada. Sedangkan pada tahun 2015 dana tabaru' yang ada nilainya lebih tinggi dibandingkan dengan pembayaran klaim.

Tabel 5: Data Asuransi PT. Takaful Keluarga

\begin{tabular}{|c|c|c|c|c|c|}
\hline Year & 2012 & 2013 & 2014 & 2015 & 2016 \\
\hline $\begin{array}{c}\text { Efficiency } \\
\text { Asuransi Syariah Al } \\
\text { Amin }\end{array}$ & 100 & 94.96 & 68.97 & 66.44 & 100 \\
\hline $\begin{array}{c}\text { Asuransi Syariah } \\
\text { Amanah Ghita }\end{array}$ & 100 & 16.68 & 32.53 & 26.5 & 66.75 \\
\hline Takaful & 100 & 90.98 & 92.94 & 93.38 & 100 \\
\hline
\end{tabular}

Sumber : Hasil olah data

Data pada asuransi Amanah Jiwa Graha memperlihatkan bahwa terdapat ketimpangan yang cukup jauh antara dana tabaru' dengan pembayaran klaim. Sebagian besar dana menunjukan bahwa pembayaran klaim yang harus dibayarkan lebih besar dimbandingkan dengan dana tabaru' yang harusnya diperoleh.

Tabel 5. Data Asuransi PT. Takaful Keluarga

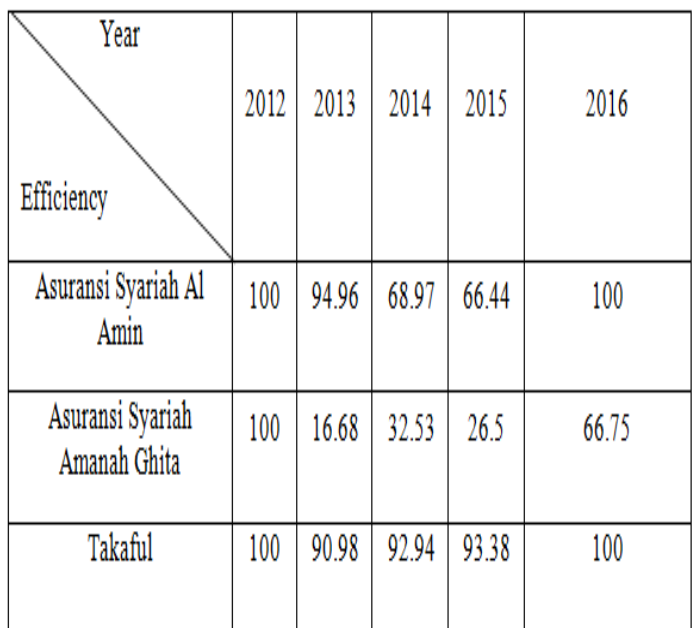

Sumber : Hasil olah data
Berbeda dengan perusahaan asuransi sebelumnya, perbandingan antara input dan output yang dihasilkan pada asuransi Takaful cukup seimbang. Apabila melihat antara dana tabaru' dan pembayaran klaim, pada tahun 2012, 2014 dan 2015 yang mengalami selisih negatif dimana pembayaran klaim lebih tinggi dibandingkan dengan perolehan dana tabaru' yang ada. Sedangkan tahun 2013 dan 2016, terdapat selisih positif antara dana tabaru' dengan pembayaran klaim, dapat diartikan perolehan dana tabaru' lebih besar dibandingkan dengan pembayaran klaim.

Untuk mengetahui tingkat efisiensi, variabel input (total aset, biaya asuransi dan klaim) dan variabel output (pendapatan dan dana tabarru). diproses menggunakan DEA. Namun, dari pengumpulan data ditemukan bahwa data klaim dari Asuransi $\mathrm{Al}$ Amin pada tahun 2012 dan 2013 serta Asuransi Syariah Amanah Ghita pada tahun 2012 adalah nol. Selanjutnya, data dari dana tabarru dari Asuransi syariah $\mathrm{Al}$ Amin pada tahun 2012 dan 2013 serta Asuransi Syariah Amanah Ghita pada tahun 2012 juga tidak berlaku. Oleh karena itu, dana klaim dan tabarru diambil dari input dan output variabel. Tabel berikut adalah hasil dari pengolahan data menggunakan DEA. 
Tabel 7. Efisiensi Asuransi Syariah di Indonesia

\begin{tabular}{|c|c|c|c|c|c|}
\hline Year & 2012 & 2013 & 2014 & 2015 & 2016 \\
\hline $\begin{array}{c}\text { Efficiency } \\
\text { Asuransi } \\
\text { Syariah Al } \\
\text { Amin }\end{array}$ & 100 & 94.96 & 68.97 & 66.44 & 100 \\
\hline $\begin{array}{c}\text { Asuransi } \\
\text { Syariah } \\
\text { Amanah } \\
\text { Ghita }\end{array}$ & 100 & 16.68 & 32.53 & 26.5 & 66.75 \\
\hline Takaful & 100 & 90.98 & 92.94 & 93.38 & 100 \\
\hline
\end{tabular}

Sumber : Hasil olah data

Dari tabel di atas, dapat dilihat bahwa sebagian besar perusahaan asuransi syariah masih belum efisien. Ini menunjukkan bahwa bentuk 5 tahun operasional masing-masing perusahaan, hanya mendapat skor efisiensi 100 dalam satu atau dua tahun. Semua perusahaan mencapai nilai 100 pada tahun 2012, selama 2013-2015 adalah penurunan untuk Asuransi Syariah Al Amin, dan berfluktuasi untuk Asuransi Syariah Amanah Ghita dan Takaful. Sedangkan pada 2016, Asuransi Syariah Al Amin, dan Takaful kembali mencapai nilai 100.

Hasil diatas sesuai dengan beberapa penelitian yang telah mengukur efisiensi asuransi syariah di Indonesia ataupun di luar negeri yang menyatakan bahwa sebagian besar asuransi syariah belum efisien. Abduh (2012) menyatakan bahwa asuransi konvensional cenderung lebih efisien jika dibandingkan dengan asuransi syariah. Tufahati, Mardian, dan Suprapto (2016) menyatakan bahwa pada 2 asuransi syariah umum yang dijadikan sampel belum ada yang mencapai tingkat efisiensi. Sedangkan 3 dari 7 sampel unit usaha asuransi syariah juga 2 belum efisien. Rusydiana dan Nugroho (2017) menyatakan bahwa secara umum perusahaan asuransi syariah di Indonesia belum efisien terutama jika dibandingkan dengan perusahan asuransi konvensional, hal ini terutama dikarenakan market share Takaful yang masih rendah. Sunarsih dan Fitriyani (2018) menyebutkan pada 2014-2016 empat perusahaan asuransi syariah tidak efisien dikarenakan oleh biaya administrasi dan umum, pembayaran klaim, investasi modal, pendapatan investasi, dan pembayaran tabarru'.

Efisiensi dapat terjadi apabila perbandingan antara input dan output sama. Sehingga apabila tidak terjadi efisiensi maka perusahaan dapat mengatasi dengan menambah jumlah input dan output atau mengurangi input dan output. Efisiensi dapat terjadi bila variabel input dan output ditambahkan atau dikurangi tersendiri atau secara bersama - sama.

Pada asuransi takaful tahun 2015 nilai dana tabaru'lebih besar daripada dana klaim, namun hal ini bukan berarti efisien, hasil menunjukan terjadi ketidakefisienan. Lebih lanjut, ketidakefisienan ini muncul karena jumlah beban cukup besar dan jumlah pendapatan tidak terlalu signifikan. Sehingga agar efisien perusahan dapat menambah jumlah pendapatan. Terdapat beberapa hal yang perlu diperhatikan agar perusahaan dapat memaksimumkan nilai efisiensinya. 
1. Memperbesar dana tabaru'

2. Meningkatkan pendapatan dengan menginvestasikan dana tabaru' pada sektor sektor yang potensial

3. Menambah jumlah asset

\section{Kesimpulan}

Kesimpulan dari penelitian ini adalah

1. Secara umum dengan menggunakan pendekatan DEA (Data Envelopment Analysis) pada perusahaan asuransi jiwa syariah tahun 2012 - 2016 sebagian besar asuransi syariah belum efisien.

2. Pada tahun 2012, semua perusahaan asuransi mencapai titik efisien. Sedangkan pada tahun 2016, 2 dari 3 perusahaan asuransi jiwa syariah yang efisien.

3. Dari perusahaan asuransi jiwa syariah yang tercatat pada OJK tidak semua perusahaan asuransi tersebut mempublikasikan data keuangannya dengan lengkap

\section{Daftar Pustaka}

\section{Al-Quran Terjemahan.} 2015.Departemen Agama RI. Bandung: CV Darus Sunnah.

Abduh, M., Omar, M. A., \& Tarmizi, R. M. (2012). The
Performance of Insurance Industry in Malaysia: Islamic vs Conventional Insurance. Journal of Islamic Banking and Finance, Vol.29 No.4.

Abidin Z, Endri. 2010. Kinerja efisiensi teknis bank pembangunan daerah: pendekatan data envelopment analysis (DEA). Jurnal Akuntansi dan Keuangan 11(1): 21-29.

Amrin, Abdullah. 2006. Asuransi Syariah.Jakarta: PT Elex Media Komputindo

Antonio MS, Ali MM, Akbar N. 2013. A comparative analysis of efficiency of takaful and conventional insurance in Malaysia. Hamdan Bin Mohammed e-University Journals.

Benarda, B., Sumarwan, U., \& Hosen, M. N. 2016. Tingkat efisiensi industri asuransi jiwa syariah menggunakan pendekatan Two Stage Data Envelopment Analysis. Jurnal Aplikasi Bisnis dan Manajemen (JABM), 2(1), 64.

DSN-MUI. 2001. Fatwa DSN MUI NO : 21/DSN-MUI/X/2001 tentang Pedoman Umum Asuransi Syariah. DSN-MUI: Jakarta

Fiafiah, Alfu Laila dan Darwanto. 2019. Technical Efficiency Level of Islamic Bank In 
Indonesia. al-Uqud: Journal of Islamic Economics, Vol 3 No. 2, 114-132. DOI: 10.26740/aluqud.v3n2.p114-132

Hassine, M. B., \& Limani, R. 2014. The Impact of Bank Characteristics on the Efficiency: Evidence from MENA Islamic Banks. Journal of Applied Finance E Banking, Vol. 4 No.2, 237-253.

Muhammad. 2007. Lembaga EkonomiSyari'ah. Yogyakarta: Graha Ilmu

Ningsih, Yulia Wahyu dan Suprayogi, Noven. 2017. Analisis Efisiensi Asuransi Umum Syariah di Indonesia Tahun 2013-2015: Aplikasi Metode Data Envelopment Analysis (DEA). Jurnal Ekonomi Syariah Teori dan Terapan, Vol. 4 No. 9: 757772 ;

Otoritas Jasa Keuangan. 2019a. Statistik Perbankan Syariah Indonesia Februari 2019.OJK:Jakarta $2019 b$.

Statistik IKNB Syariah Februari 2019.OJK:Jakarta

Republik Indonesia. 1992. Undangundang Republik Indonesia No. 2 Tahun 1992 tentang Usaha Perasuransian, Sekretariat Negara:Jakarta
Republik Indonesia. 2014. UndangUndangRepublik Indonesia Nomor 40 Tahun 2014 tentang Perasuransian. SekretariatNegara. Jakarta.

Rusydiana, A. S., \& Nugroho, T. (2017). Measuring Efficiency of Life Insurance Institution in Indonesia: Data Envelopment Analysis Approach. Global Review of Islamic Economics and Business, 5(1), 012-024.

Sabiti MB, Effendi J, Novianti T. 2017. Efisiensi Asuransi Syariah di Indonesia. Jurnal Al-Muzara'ah, Vol.5, No.1.

Sunarsih, Fitriyah. 2018. Analisis Efisiensi Asuransi Syariah di Indonesia tahun2014-2016 dengan metode Data Envelopment Analysis (DEA). Jurnal Ekonomi EKeuangan Islam, 4(1):9-21. doi 10.20885/JEKI.vol4.iss1.art2

Tuffahati, H., Mardian, S., Suprapto, E. 2016. Pengukuran Efisiensi Asuransi Syariah Dengan Data Envelopment Analysis (DEA). Jurnal Akuntansi Dan Keuangan Islam, 4(1). Retrieved from https://jurnal.sebi.ac.id/ind ex.php/jaki/article/view/59 